\title{
KETAHANAN BEBERAPA GENOTIPE PADI TERHADAP PENYAKIT HAWAR DAUN BAKTERI (XANTHOMONAS ORYZAE PV. ORYZAE)
}

\author{
Wira Hadianto ${ }^{1,2}$, Lukman Hakim ${ }^{1}$, \& Bakhtiar $^{1}$ \\ 'Program Studi Magister Agroekoteknologi, Program Pasca Sarjana Universitas Syiah Kuala \\ Jl. Tgk. Hasan Krueng Kalee, No. 3. Kopelma Darussalam, Banda Aceh 23111 \\ ${ }^{2}$ Program Studi Agroteknologi Universitas Teuku Umar \\ J1. Alue Penyareng, Meulaboh 23615 \\ E-mail: bakhtiar_fp@unsyiah.ac.id
}

\begin{abstract}
The resistance rice genotypes against bacterial leaf blight (Xanthomonas oryzae pv. oryzae). The research was conducted to analyze genotypes of rice that were resistant to bacterial leaf blight (BLB) disease. The experiment was conducted at the screen house of Faculty of Agriculture, Syiah Kuala University, Banda Aceh from February to October 2014. This experiment was arranged in randomized complete block design with 73 treatments and 3 replications. IR-BB27 and IR-64 were used as control of resistant and susceptible varieties to BLB, respectively. The result showed that the bacterial isolates tested were virulent. The longest incubation period found in Limboto, Inpari 10, Situ Patenggang, Sirendeh Semantuk Wayla, Tamboen, Sepasie, Bontok and Arias. Genotypes Inpari 1, Limboto, Tuwoti, Inpari 10, Lekat Rambot Linuet, Rom Mokot, Paki Gajah, Tamboen, Bo 100, Sipasie, Bo Minyek, Bontok, Sirendeh Semantuk Wayla and Sambei showed resistance reaction to bacterial leaf blight disease.
\end{abstract}

Key words: bacterial leaf blight, rice genotypes, Xanthomonas oryzae pv. oryzae

\begin{abstract}
ABSTRAK
Ketahanan beberapa genotipe padi terhadap penyakit hawar daun bakteri (Xanthomonas oryzae pv. oryzae). Penelitan ini bertujuan untuk mendapatkan genotipe padi yang tahan terhadap penyakit hawar daun bakteri (HDB). Penelitian dilaksanakan di screen house Fakultas Pertanian Universitas Syiah Kuala, Banda Aceh, pada bulan Februari sampai Oktober 2014. Rancangan yang digunakan adalah Rancangan Acak Kelompok dengan 73 perlakuan dan 3 ulangan. IR-BB27 digunakan sebagai pembanding tahan dan IR-64 sebagai pembanding rentan terhadap HDB. Hasil penelitian menunjukkan isolat bakteri yang diuji virulen. Masa inkubasi paling lama dijumpai pada genotipe Limboto, Inpari 10, Situ Patenggang, Sirendeh Semantuk Wayla, Tamboen, Sepasie, Bontok dan Arias. Padi genotipe IR-BB27, Inpari 1, Limboto, Tuwoti, Inpari 10, Lekat Rambot Linuet, Rom Mokot, Paki Gajah, Tamboen, Bo 100, Sipasie, Bo Minyek, Bontok, Sirendeh Semantuk Wayla dan Sambei yang menunjukan reaksi tahan terhadap HDB.
\end{abstract}

Kata kunci: genotipe padi, hawar daun bakteri, Xanthomonas oryzae pv. oryzae

\section{PENDAHULUAN}

Penyakit hawar daun bakteri (HDB) merupakan salah satu faktor pembatas dalam peningkatan produksi padi. Penyakit HDB disebabkan oleh Xanthomonas oryzae pv. oryzae (Xoo), yang dapat menurunkan hasil padi $30-40 \%$ dan menurunkan mutu beras yang dihasilkan. Penyakit ini menginfeksi pada fase vegetatif hingga fase generatif (Herlina \& Silitonga, 2011). Xanthomonas oryzae pv. oryzae (Xoo) menginfeksi tanaman dengan cara masuk ke dalam jaringan tanaman melalui lubang alami seperti hidatoda dan benih yang terkontaminasi $(\mathrm{Ou}, 1985)$. Gejala dari serangan Xoo menyebabkan daun padi berubah menjadi kuning pucat, layu, dan kemudian mati (Wahyudi et al., 2011). Salah satu upaya pengendalian penyakit HDB dengan penggunaan varietas tahan. Varietas tahan lebih aman digunakan karena tidak mencemari lingkungan dibandingkan dengan penggunaan pestisida yang meninggalkan residu. Varietas yang tahan dapat diperoleh melalui perakitan varietas dengan menggabungkan gen ketahanan pada tetua yang telah beradaptasi dan berdaya hasil tinggi.

Perakitan varietas tahan diawali dengan identifikasi genotipe sebagai tetua untuk pembentukan populasi dasar. Penggunaan gen-gen tahan terhadap berbagai cekaman yang dimiliki varietas lokal dalam pemuliaan tanaman dapat meningkatkan keunggulan varietas unggul yang akan dihasilkan (Berthaud et al., 2000). Padi lokal dapat dijadikan sebagai tetua untuk 
memperoleh varietas unggul yang mempunyai sifat morfologi dan fisiologi yang lebih baik, seperti gabah hampa lebih sedikit dan lebih tahan terhadap hama dan penyakit utama (Abdullah, 2009). Dengan demikian, varietas lokal yang dibudidayakan secara turun temurun oleh petani merupakan salah satu sumber daya genetik bagi perakitan varietas.

Provinsi Aceh memiliki banyak varietas lokal yang masih dibudidayakan petani terutama di daerah Aceh Barat-Selatan. Bakhtiar et al. (2011) melaporkan bahwa varietas lokal padi Aceh sangat beragam. Namun demikian, potensi varietas tersebut sebagai sumber gen ketahanan terhadap HDB belum dievaluasi.

Berdasarkan permasalahan di atas diperlukan suatu penelitian untuk mengevaluasi ketahanan beberapa genotipe padi terhadap penyakit hawar daun bakteri. Tujuan penelitian adalah untuk mengetahui dan mendapatkan genotipe padi yang tahan terhadap penyakit HDB.

\section{METODE PENELITIAN}

Tempat dan Waktu. Penelitian dilaksanakan di kebun percobaan Fakultas Pertanian, Universitas Syiah Kuala, Banda Aceh, bulan Februari sampai dengan Oktober 2014. Rancangan yang digunakan adalah rancangan acak kelompok (RAK) dengan 73 genotipe padi sebagai perlakuan dan 3 ulangan. Genotipe IR-BB27 digunakan sebagai pembanding tahan dan genotipe IR-64 sebagai pembanding rentan terhadap penyakit HDB.

Bahan Tanam. Bahan tanam yang digunakan terdiri dari 71 genotipe tanaman padi, yang terdiri atas varietas unggul nasional sebanyak 16 genotipe, varietas lokal Aceh tipe ketan sebanyak 11 genotipe dan varietas lokal Aceh tipe bukan ketan sebanyak 44 genotipe.

Persiapan Benih. Benih terlebih dahulu direndam dengan air bersih selama satu malam untuk proses imbibisi, kemudian benih dikecambahkan selama dua hari dengan cara dibalut dengan kain lembab. Setelah berkecambah benih tersebut dipindahkan ke wadah persemaian yang telah disiapkan. Media tanam adalah tanah alluvial yang dimasukkan dalam bak plastik dan diberikan air, selanjutnya diaduk sampai merata.

Persiapan Inokulum. Daun padi varietas Ciherang yang terinfeksi HDB dikumpulkan dari Gampong Blang Kecamatan Blang Bintang Kabupaten Aceh Besar, pada musim tanam 2013/2014. Persiapan inokulum mengikuti prosedur yang dilakukan Shehzad et al. (2012), daun terinfeksi HDB dibilas dengan air, kemudian dipotong- potong 5-10 $\mathrm{mm}$ dan disterilisasi dengan etanol 70\% selama 10 detik dan disimpan pada cawan Petri selama 20 menit supaya bacterial ooze-keluar. Media Nutrient Agar (NA) digunakan untuk mengisolasi inokulum yang diinkubasikan selama 3 hari sampai muncul koloni kuning.

Biakan murni bakteri disimpan pada media agar miring pada suhu $20-25{ }^{\circ} \mathrm{C}$ agar terhindar dari kontaminasi. Pada saat akan digunakan, koloni bakteri diukur konsentrasinya setara dengan $10^{6} \mathrm{sel} \mathrm{hidup} / \mathrm{ml}$. Inokulum yang disiapkan dalam media NA $20 \mathrm{~g} / 1$ akuades, selanjutnya dimasukkan ke dalam Erlenmeyer yang dibalut dengan aluminium foil, kemudian siap diinokulasi pada daun padi.

Uji Hipersensitivitas. Uji hipersensitivitas isolat bakteri terhadap tanaman tembakau dilakukan menurut Zou et al. (2006). Koloni hawar daun bakteri hasil isolasi dengan kerapatan $\pm 10^{6} \mathrm{sel} / \mathrm{ml}$ dalam kultur cair disuntikkan ke tulang daun tanaman tembakau. Sebagai kontrol, pada tulang daun tembakau lainnya disuntik dengan akuades. Pengamatan gejala penyakit dilakukan hingga 48 jam setelah penyuntikan dan difoto.

Penanaman dan Inokulasi Bakteri. Semua bahan tanam ditanam masing-masing sebanyak 5 tanaman dalam 1 ulangan. Penanaman dilakukan dalam bak plastik dan ditempatkan dalam screen house Fakultas Pertanian Unsyiah, Banda Aceh. Pengendalian hama menggunakan insektisida karbofuran 3G dengan takaran $20 \mathrm{~kg}$ formulasi/ha. Untuk mendorong perkembangan penyakit $\mathrm{HDB}$, tanaman diberi pupuk $\mathrm{N}$ dengan takaran $250 \mathrm{~kg}$ urea/ha. Agar bakteri tidak dihadapkan pada suhu yang terlalu panas, inokulasi dilakukan menjelang sore, antara pukul 16.00-18.00. Inokulasi dilakukan dengan cara pengguntingan daun padi untuk pelukaan sebagai jalan masuk bagi infeksi bakteri. Pengguntingan dilakukan 3-5 cm dari ujung daun, menggunakan gunting yang telah dicelupkan ke dalam Erlenmeyer berisi suspensi isolat bakteri dengan kerapatan $10^{6}$ sel hidup/ ml. Inokulasi tanaman dengan isolat bakteri Xanthomonas oryzae pv. oryzae dilakukan satu kali, yaitu pada saat tanaman berumur $42 \mathrm{HST}$ atau memasuki fase vegetatif aktif.

Suhu dan Kelembaban. Diamati setiap hari mulai inokulasi penyakit sampai 14 hari setelah inokulasi.

Masa inkubasi. Masa inkubasi dihitung dari saat inokulasi sampai munculnya gejala penyakit yang dilakukan setiap hari hingga 14 hari setelah inokulasi dalam satuan hari. 
Panjang lesio. Panjang lesio diamati 14 hari setelah inokulasi dengan cara mengukur panjang lesio dari lima daun per tanaman, kemudian dihitung rata-ratanya dalam satuan $\mathrm{cm}$.

\section{HASIL DAN PEMBAHASAN}

Uji Hipersensitivitas. Uji hipersensitivitas dilakukan untuk mengetahui patogenesitas patogen atau kemampuan patogen dalam menyebabkan penyakit. Tanaman tembakau digunakan sebagai tanaman indikator untuk uji hipersensitif (Suswanto et al., 1996). Bakteri Xanthomonas oryzae pv. oryzae (Xoo) yang disuntik pada tulang daun tanaman tembakau mampu menginduksi reaksi hipersensitif. Daun tembakau menjadi kecoklatan pada area masuknya bakteri. Reaksi ini paling jelas teramati 48 jam setelah penyuntikan. Sebagai kontrol negatif yang disuntik dengan akuades tidak menunjukkan reaksi serupa (Gambar 1).

Respon hipersensitif diartikan sebagai reaksi pertahanan yang cepat dari tanaman menghadapi patogen yang tidak kompatibel disertai dengan kematian sel yang cepat pada jaringan di daerah yang diinjeksi suspensi bakteri (Klement et al., 1990). Dengan demikian bakteri yang diisolasi dari lapangan tersebut dapat digunakan sebagai inokulum untuk evaluasi ketahanan terhadap HDB dari 73 genotipe padi yang akan diuji.

Suhu. Pada penelitian ini, suhu udara dicatat setiap hari sejak inokulasi sampai pengamatan gejala penyakit terakhir, yaitu 14 HSI. Suhu minimum $22{ }^{\circ} \mathrm{C}$ dan maksimum $34{ }^{\circ} \mathrm{C}$ dengan rata-rata $27,04{ }^{\circ} \mathrm{C}$ selama penelitian. Menurut Devadath (1989) perkembangan gejala HDB akan lebih cepat pada suhu tinggi dibanding suhu rendah dimana suhu optimal berkisar antara 24,3$34{ }^{\circ} \mathrm{C}$. Selanjutnya, Wiyono (2007) menyebutkan bakteri penyebab penyakit kresek pada padi menghendaki suhu optimum pada $30^{\circ} \mathrm{C}$. Hal ini menunjukkan bahwa suhu selama percobaan mendukung perkembangan penyakit HDB.

Kelembaban. Kelembaban udara yang cukup tinggi akan meningkatkan pertumbuhan penyakit hawar daun bakteri. Pada penelitian ini, kelembaban udara diamati setiap hari sejak inokulasi sampai pengamatan gejala penyakit terakhir pada $14 \mathrm{HSI}$. Kelembaban udara selama pengamatan gejala penyakit berada pada kisaran 43,60-68,23\% dengan rata-rata 53,18\%. Menurut Sudir et al. (2012), kelembaban yang tinggi dapat mempercepat perkembangan penyakit ini. Hal ini menunjukkan bahwa kondisi kelembaban pada penelitian ini dapat meningkatkan infeksi penyakit HDB yang diinokulasi pada daun padi.

Masa Inkubasi. Hasil pengamatan terhadap masa inkubasi bakteri Xoo pada beberapa genotipe varietas unggul nasional disajikan pada Tabel 1. Gejala penyakit hawar daun pada varietas yang diuji ditandai dengan munculnya gejala hijau kelabu selanjutnya menguning berdekatan dengan ujung daun yang dipotong. Gejala penyakit tersebut terus memanjang di sepanjang tepi daun (Gambar 2).

Masa inkubasi bakteri hawar daun bakteri pada 16 genotipe varietas unggul nasional yang diuji berkisar 4 sampai 10,67 hari setelah inokulasi. Gejala penyakit paling cepat muncul dijumpai pada varietas Inpari 7 dan Ipari 16, yaitu 4,67 hari setelah inokulasi. Gejala penyakit pada IR-64 sebagai pembanding rentan mulai muncul pada 8,67 hari setelah inokulasi. Gejala penyakit paling lama muncul pada genotipe unggul dijumpai pada Limboto, Inpari 10, dan Situ Patenggang yang tidak jauh berbeda dibandingkan masa inkubasi pada pembanding tahan yaitu galur IR-BB27, yaitu 12 hari setelah inokulasi (Tabel 1).
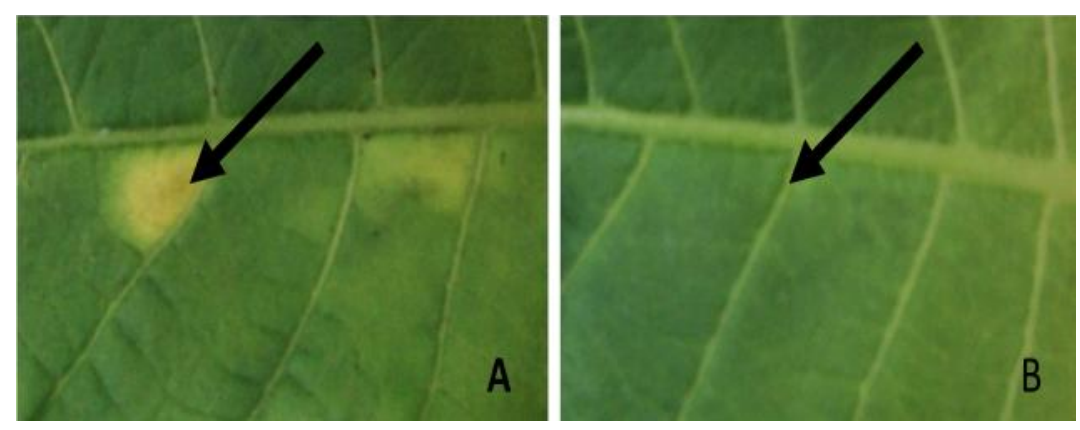

Gambar 1. Hasil uji hipersensitivitas setelah disuntik membentuk lesio pada daun tembakau yang terinfeksi bakteri Xoo (A), kontrol negatif (B) 
Hasil pengamatan terhadap masa inkubasi bakteri Xoo pada beberapa genotipe padi lokal Aceh tipe ketan disajikan pada Tabel 2. Masa inkubasi bakteri hawar daun bakteri pada 11 genotipe tipe ketan yang diuji berkisar 3 sampai 9 hari setelah inokulasi. Gejala penyakit paling cepat muncul dijumpai pada genotipe Pulut Merah, yaitu 3,33 hari setelah inokulasi. Gejala penyakit paling lama dijumpai pada genotipe Lekat Rambot Lineut yaitu muncul 9,33 hari setelah inokulasi tetapi lebih cepat dibandingkan gejala penyakit pada IRBB27 sebagai pembanding tahan (Tabel 2).

Hasil pengamatan terhadap periode inkubasi bakteri Xoo pada beberapa genotipe padi lokal Aceh tipe bukan ketan disajikan pada Tabel 3. Periode inkubasi bakteri hawar daun bakteri pada 44 genotipe padi lokal bukan ketan yang diuji berkisar 3 sampai 11 hari setelah inokulasi. Gejala penyakit paling cepat muncul dijumpai pada genotipe Pade Merah Lamtuba, yaitu 3,67 hari setelah inokulasi. Gejala penyakit paling lama muncul dijumpai pada Sirendeh Semantuk Wayla yaitu 11 hari setelah inokulasi hampir sama dengan gejala penyakit pada IR-BB27 sebagai pembanding tahan (Tabel 3).

Hasil penelitian terhadap masa inkubasi bakteri Xoo pada 71 genotipe yang diuji penyakit HDB terlihat bahwa genotipe varietas unggul nasional dengan masa inkubasi tercepat dijumpai pada varietas Inpari 16 dan Inpari 7 (4,67 hari). Genotipe padi lokal Aceh tipe ketan dengan masa inkubasi tercepat dijumpai pada genotipe Pulut Merah (3,33 hari) dan genotipe padi lokal Aceh tipe bukan ketan dengan masa inkubasi tercepat pada genotipe Pade Merah Lamtuba (3,67 hari). Gejala penyakit pada IR-64 sebagai pembanding rentan mulai

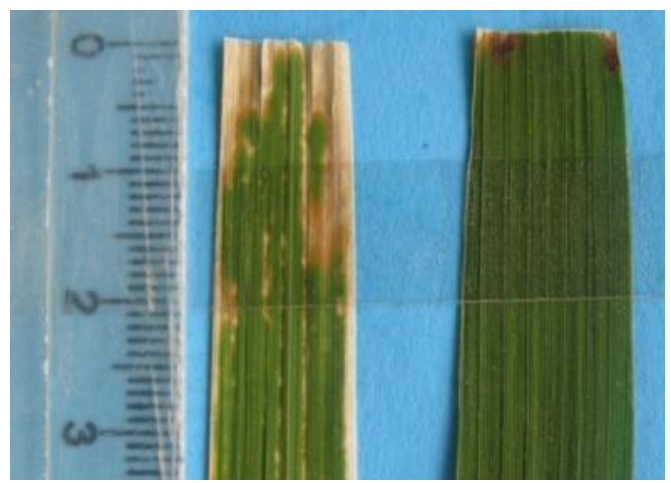

Gambar 2. Gejala HDB pada daun padi yang diinokulasi dengan Xoo (kiri) dan tidak memperlihatkan gejala pada daun padi tanpa Xoo (kanan)

Tabel 1. Masa inkubasi pada varietas unggul nasional

\begin{tabular}{|c|c|c|}
\hline No & Genotipe unggul & Masa inkubasi (hari) \\
\hline 1 & IR-BB27 (kontrol tahan) & $12,00 \pm 1,00$ \\
\hline 2 & Limboto & $10,67 \pm 0,58$ \\
\hline 3 & Inpari 10 & $10,33 \pm 2,08$ \\
\hline 4 & Situ Patenggang & $10,00 \pm 1,73$ \\
\hline 5 & IPB $4 \mathrm{~S}$ & $9,67 \pm 1,53$ \\
\hline 6 & Situ Bagendit & $9,67 \pm 1,53$ \\
\hline 7 & Ciherang & $9,67 \pm 2,52$ \\
\hline 8 & Inpari 1 & $9,33 \pm 1,53$ \\
\hline 9 & Inpari 19 & $9,33 \pm 2,08$ \\
\hline 10 & Cirata & $8,67 \pm 1,15$ \\
\hline 11 & IPB 3S & $8,67 \pm 1,15$ \\
\hline 12 & Tuwoti & $8,67 \pm 0,58$ \\
\hline 13 & Inpago 6 & $7,67 \pm 0,58$ \\
\hline 14 & Danau Gaung & $6,33 \pm 1,53$ \\
\hline 15 & Kencana Bali & $5,00 \pm 1,73$ \\
\hline 16 & Inpari 16 & $4,67 \pm 1,53$ \\
\hline 17 & Inpari 7 & $4,67 \pm 1,15$ \\
\hline 18 & IR-64 (kontrol rentan) & $8,67 \pm 1,53$ \\
\hline
\end{tabular}


muncul pada 8.67 hari setelah inokulasi. Hal ini menunjukkan bahwa genotipe tersebut rentan terhadap penyakit HDB yang terlihat dari cepat terinfeksi oleh penyakit yang diinokulasi dengan Xoo pada daun padi.

Masa inkubasi bakteri Xoo terlama dijumpai pada varietas pembanding IR-BB27 yaitu 12 hari setelah inokulasi, sedangkan pada varietas unggul nasional dijumpai pada Limboto, Inpari 10, dan Situ Patenggang. Genotipe padi lokal Aceh tipe ketan dengan masa inkubasi terlama dijumpai pada genotipe Lekat Rambot Lineut (9,33 hsi) dan genotipe padi lokal Aceh tipe bukan ketan dengan masa inkubasi terlama pada genotipe Sirendeh Semantuk Wayla (11 hsi). Hal ini menunjukkan bahwa genotipe tersebut memiliki ketahanan terhadap infeksi penyakit HDB dapat dilihat lamanya muncul gejala serangan. Masa inkubasi penyakit menjadi salah satu faktor yang menentukan virulensi suatu patogen, demikan pula sebaliknya masa inkubasi penyakit yang lama menandakan suatu varietas tahan terhadap suatu patogen (Rahim et al., 2012). Genotipe tahan memiliki gen ketahanan terhadap ras/patotipe Xoo yang dikendalikan oleh gen R mayor (Nino-Liu et al., 2006).

Masa inkubasi bakteri Xoo pada fase vegetatif dari 71 genotipe yang diuji dengan dibagi tiga kriteria yaitu lama, sedang sampai cepat (Tabel 4). IR-64 tergolong kedalam genotipe dengan masa inkubasi penyakit HDB sedang, dengan demikian, varietas IR64 cocok digunakan sebagai kontrol rentan. IR-BB27 tergolong ke dalam genotipe dengan masa inkubasi penyakit HDB lama sehingga IR-BB27 cocok digunakan sebagai kontrol tahan berdasarkan muncul gejala penyakit terhadap HDB.

Panjang Lesio. Hasil pengamatan terhadap panjang lesio bakteri Xoo pada beberapa genotipe varietas unggul nasional disajikan pada Tabel 5. Panjang lesio yaitu reaksi gejala layu pada ujung daun dan muncul bercak kelabu pada tepi daun yang kemudian mulai berkerut seluruh bagian daun mulai berwarna putih kecoklatan dan kuning pucat menuju pangkal daun. Panjang lesio bakteri hawar daun bakteri pada 17 genotipe varietas unggul nasional yang diuji berkisar 1,42 sampai 19,09 cm. Panjang lesio terpendek dijumpai pada pembanding tahan galur IRBB27 dan varietas Inpari 1, yaitu $1,42 \mathrm{~cm}$. Panjang lesio terpanjang dijumpai pada varietas Inpari 16, yaitu 19,09 $\mathrm{cm}$ (Tabel 5). Panjang lesio pada varietas IR-64 sebagai pembanding rentan yaitu $7,43 \mathrm{~cm}$.

Panjang lesio pada varietas Inpari 1, Limboto, Tuwoti, dan Inpari 10 berbeda tidak nyata dibandingkan panjang lesio pada genotipe pembanding IR-BB27 (Tabel 5). Hal ini menunjukkan bahwa varietas tersebut tahan terhadap HDB. Panjang lesio pada varietas Danau Gaung, IPB 4 S, Situ Bagendit, Inpago, Cirata dan IPB 3S berbeda nyata dibandingkan panjang lesio pada genotipe pembanding IR-BB27 (Tabel 5). Hal ini menunjukkan bahwa varietas tersebut moderat tahan terhadap HDB. Panjang lesio pada varietas Ciherang, Situ Patenggang, Kencana Bali, Inpari 19, Inpari 7 dan Inpari 16 berbeda sangat nyata dibandingkan panjang lesio pada genotipe pembanding IR-BB27 (Tabel 5). Hal ini menunjukkan bahwa varietas tersebut rentan terhadap HDB.

Panjang lesio bakteri Xoo pada padi lokal Aceh tipe ketan disajikan pada Tabel 6. Panjang lesio bakteri hawar daun bakteri pada 11 genotipe tipe ketan yang diuji berkisar 3,06 sampai 19,39 cm. Panjang lesio terpendek dijumpai pada genotipe Lekat Rambot Lineut, yaitu $3,6 \mathrm{~cm}$. Panjang lesio terpanjang dijumpai pada genotipe Lekat Tuleng, yaitu 19,93 cm. Panjang lesio

Tabel 2. Masa inkubasi pada genotipe padi lokal Aceh tipe ketan

\begin{tabular}{clr}
\hline \multicolumn{1}{c}{ Genotipe ketan } & Masa inkubasi (hari) \\
\hline 1 & IR-BB27 & $12,00 \pm 1,00$ \\
2 & Leukat Rambot Lineut & $9,33 \quad \pm 0,58$ \\
3 & Pulut Hitam & $9,00 \pm \pm 1,00$ \\
4 & Ketan Putih & $8,67 \pm 1,53$ \\
5 & Lekat Singke & $8,00 \pm 0,00$ \\
6 & Lekat jerajak Lango & $8,00 \pm 1,00$ \\
7 & Lekat Adang & $8,00 \pm 1,00$ \\
8 & Lekat Alahu & $7,67 \pm 2,31$ \\
9 & Pulut Simanik & $6,33 \pm 0,58$ \\
10 & Lekat Tuleng & $4,67 \pm 2,08$ \\
11 & Lekat Kumbob & $4,33 \pm 0,58$ \\
12 & Pulut Merah & $3,33 \quad \pm 0,58$ \\
\hline
\end{tabular}


Tabel 3. Masa inkubasi pada genotipe padi lokal Aceh bukan ketan

\begin{tabular}{|c|c|c|c|}
\hline \multirow{2}{*}{$\frac{\text { No }}{1}$} & \multirow{2}{*}{$\begin{array}{l}\text { Genotipe lokal bukan ketan } \\
\text { IR-BB27 }\end{array}$} & \multicolumn{2}{|c|}{ Masa inkubasi (hari) } \\
\hline & & $12,00=$ & $\pm 1,00$ \\
\hline 2 & Sirendeh Semantuk Wayla & $11,00=$ & $\pm 1,73$ \\
\hline 3 & Tamboen & $10,33=$ & $\pm 1,15$ \\
\hline 4 & Sepasie & $10,33=$ & $\pm 0,58$ \\
\hline 5 & Bontok & $10,00=$ & $\pm 1,00$ \\
\hline 6 & Arias & $10,00=$ & $\pm 2,65$ \\
\hline 7 & Paki Gajah & $9,67=$ & $\pm 1,53$ \\
\hline 8 & Pade Kapai Tamping & $9,67=$ & $\pm 1,53$ \\
\hline 9 & Bo Rayek Semantok Wayla & $9,67=$ & $\pm 1,53$ \\
\hline 10 & Sambei & $9,00=$ & $\pm 2,00$ \\
\hline 11 & Rom Mokot & $8,67=$ & $\pm 1,15$ \\
\hline 12 & Pade Jamai Asan & $8,67=$ & $\pm 3,06$ \\
\hline 13 & Manyam & $8,67=$ & $\pm 1,53$ \\
\hline 14 & Sigupai Blang Pidie & $8,67=$ & $\pm 1,15$ \\
\hline 15 & Pade Pineng Lango & $8,67=$ & $\pm 1,53$ \\
\hline 16 & Pandan Wangi & $8,33=$ & $\pm 1,53$ \\
\hline 17 & Pala Gajah & $8,33=$ & $\pm 1,53$ \\
\hline 18 & Sepulou & $8,33=$ & $\pm 1,53$ \\
\hline 19 & Rom Lambo & $8,33=$ & $\pm 1,52$ \\
\hline 20 & Padi Sitandun & $8,00=$ & $\pm 1,00$ \\
\hline 21 & Rom Ilang & $8,00=$ & $\pm 1,00$ \\
\hline 22 & Bo 100 & $8,00=$ & $\pm 2,00$ \\
\hline 23 & Bo Minyek & 8,00 & $\pm 2,00$ \\
\hline 24 & Asahan & $7,67=$ & $\pm 0,58$ \\
\hline 25 & Boh Penileh & $7,67=$ & $\pm 2,08$ \\
\hline 26 & Sirias & $7,67=$ & $\pm 0,58$ \\
\hline 27 & Dewi & $7,33=$ & $\pm 0,58$ \\
\hline 28 & Kuku Balam & $7,33=$ & $\pm 1,53$ \\
\hline 29 & Seraguek & $7,33=$ & $\pm 3,21$ \\
\hline 30 & Sigupai Pulo & $7,33=$ & $\pm 1,53$ \\
\hline 31 & Sirangkoh Lubok Pasi & 7,00 & $\pm 1,00$ \\
\hline 32 & Bo Somboh Meon & 7,00 & $\pm 3,61$ \\
\hline 33 & Sigupai Wangi & $7,00=$ & $\pm 1,00$ \\
\hline 34 & Bo Santet Semantok & $7,00=$ & $\pm 2,00$ \\
\hline 35 & Saguek & $7,00=$ & $\pm 1,00$ \\
\hline 36 & Cantek Manis & $6,67=$ & $\pm 1,53$ \\
\hline 37 & Jeumpa Puteh & $6,67=$ & $\pm 2,52$ \\
\hline 38 & Ramos Tihion Tamping & $6,67=$ & $\pm 1,53$ \\
\hline 39 & Salah Manyang & $6,33=$ & $\pm 0,58$ \\
\hline 40 & Semerebuk & $6,00=$ & $\pm 1,00$ \\
\hline 41 & Sijane & $5,67=$ & $\pm 0,58$ \\
\hline 42 & Kepala Gajah & 5,00 & $\pm 1,00$ \\
\hline 43 & Siputeh & $5,00=$ & $\pm 2,00$ \\
\hline 44 & Rangkoh Merah & $4,67=$ & $\pm 0,58$ \\
\hline 45 & Pade Merah Lamtuba & $3,67=$ & $\pm 1,15$ \\
\hline
\end{tabular}


Tabel 4. Pengelompokan genotipe berdasarkan masa inkubasi penyakit HDB

\begin{tabular}{|c|c|c|c|}
\hline No & $\begin{array}{l}\text { Masa inkubasi } \\
\quad \text { (hari) }\end{array}$ & Kriteria & Genotipe \\
\hline 1. & $>10$ hari & Lama & $\begin{array}{l}\text { IR-BB27, Limboto, Inpari 10, Situ Patenggang, Sirendeh Semantuk } \\
\text { Wayla, Tamboen, Sepasie, Bontok dan Arias }\end{array}$ \\
\hline 2. & $8-10$ hari & Sedang & $\begin{array}{l}\text { IPB } 4 \text { S, Situ Bagendit, Ciherang, Inpari 1, Inpari 19, Cirata, IPB 3S, } \\
\text { Tuwoti, IR-64, Leukat Rambot Lineut, Pulut Hitam, Ketan Putih, } \\
\text { Lekat Singke, Lekat jerajak Lango, Lekat Adang, Paki Gajah, Pade } \\
\text { Kapai Tamping, Bo Rayek Semantok Wayla, Sambei, Rom Mokot, } \\
\text { Pade Jamai Asan, Manyam, Sigupai Blang Pidie, Pade Pineng Lango, } \\
\text { Pandan Wangi, Pala Gajah, Sepulou, Rom Lambo, Padi Sitandun, } \\
\text { Rom Ilang, Bo } 100 \text { dan Bo Minyek }\end{array}$ \\
\hline 3. & $<8$ hari & Cepat & $\begin{array}{l}\text { Inpago 6, Danau Gaung, Kencana Bali, Inpari 16, Inpari 7, Lekat } \\
\text { Alahu, Pulut Simanik, Lekat Tuleng, Lekat Kumbob, Pulut Merah, } \\
\text { Asahan, Boh Penileh, Sirias, Dewi, Kuku Balam, Seraguek, Sigupai } \\
\text { Pulo, Sirangkoh Lubok Pasi, Bo Somboh Meon, Sigupai Wangi, Bo } \\
\text { Santet Semantok, Saguek, Cantek Manis, Jeumpa Puteh, Ramos } \\
\text { Tihion Tamping, Salah Manyang, Semerebuk, Sijane, Kepala Gajah, } \\
\text { Siputeh, Rangkoh Merah dan Pade Merah Lamtuba }\end{array}$ \\
\hline
\end{tabular}

Tabel 5. Rata-rata panjang lesio pada beberapa genotipe dibandingkan dengan genotipe IR-BB27 varietas unggul nasional

\begin{tabular}{clrl}
\hline \multicolumn{1}{c}{ No } & Genotipe unggul & Panjang Lesio $(\mathrm{cm})$ \\
\hline 1 & IR-BB27 & 1,42 & \\
2 & Inpari 1 & 1,42 & tn \\
3 & Limboto & 1,90 & tn \\
4 & Tuwoti & 2,11 & tn \\
5 & Inpari 10 & 2,11 & tn \\
6 & Danau Gaung & 4,27 & $*$ \\
7 & IPB 4 S & 4,39 & $*$ \\
8 & Situ Bagendit & 4,49 & $*$ \\
9 & Inpago 6 & 4,62 & $*$ \\
10 & Cirata & 4,62 & $*$ \\
11 & IPB 3S & 4,81 & $*$ \\
12 & Ciherang & 7,53 & $* *$ \\
13 & Situ Patenggang & 8,45 & $* *$ \\
14 & Kencana Bali & 13,73 & $* *$ \\
15 & Inpari 19 & 15,28 & $* *$ \\
16 & Inpari 7 & 17,99 & $* *$ \\
17 & Inpari 16 & 19,09 & $* *$ \\
18 & IR-64 & 7,43 & $* *$ \\
\hline
\end{tabular}

tn = tidak nyata; $*=$ nyata; $* *$ = sangat nyata dibandingkan IR-BB27. 
pada galur IR-BB27 sebagai pembanding tahan yaitu $1,42 \mathrm{~cm}$ (Tabel 6).

Panjang lesio pada genotipe padi lokal Aceh tipe ketan Leukat Rambot Lineut tidak berbeda nyata dibandingkan panjang lesio pada genotipe pembanding IR-BB27 (Tabel 6). Hal ini menunjukkan bahwa genotipe tersebut tahan terhadap HDB. Panjang lesio pada genotipe padi lokal Aceh tipe ketan Lekat Adang, Lekat jerajak Lango, Pulut Hitam, Lekat Singke, Lekat Alahu, Ketan Putih, Pulut Merah, Pulut Simanik, Lekat Kumbob dan Lekat Tuleng berbeda sangat nyata dibandingkan panjang lesio pada genotipe pembanding IR-BB27 (Tabel 6). Hal ini menunjukkan bahwa genotipe tersebut rentan terhadap HDB.

Hasil pengamatan terhadap panjang lesio bakteri Xoo pada beberapa genotipe padi lokal Aceh tipe bukan ketan disajikan pada Tabel 7. Panjang lesio bakteri hawar daun bakteri pada 44 genotipe padi lokal bukan ketan yang diuji berkisar 1,91 sampai $14,74 \mathrm{~cm}$. Panjang lesio terpendek dijumpai pada genotipe Rom Mokot, yaitu 1,91 $\mathrm{cm}$. Lesio terpanjang dijumpai pada Siputeh, yaitu 14,74 $\mathrm{cm}$ (Tabel 7). Panjang lesio pada galur IR-BB27 sebagai pembanding tahan yaitu $1,42 \mathrm{~cm}$.

Panjang lesio pada genotipe Rom Mokot, Paki Gajah, Tamboen, Bo 100, Sipasie, Bo Minyek, Bontok, Sirendeh Semantuk Wayla dan Sambei berbeda tidak nyata dibandingkan panjang lesio pada genotipe pembanding IR-BB27 (Tabel 7). Hal ini menunjukkan bahwa genotipe tersebut tahan terhadap HDB. Panjang lesio pada genotipe Pade Jamai Asan, Salah Manyang, Arias, Pandan Wangi dan Pade Merah Lamtuba berbeda nyata dibandingkan panjang lesio pada genotipe pembanding IR-BB27 (Tabel 7). Hal ini menunjukkan bahwa genotipe tersebut moderat tahan terhadap HDB.

Panjang lesio pada genotipe Bo Somboh Meon, Sigupai Wangi, Kuku Balam, Kepala Gajah, Asahan, Manyam, Boh Penileh, Saguek, Dewi, Jeumpa Puteh, Sigupai Blang Pidie, Pala Gajah, Rangkoh Merah, Pade Kapai Tamping, Sitandun, Sirangkoh Lubok Pasi, Sepulou, Pade Pineng Lango, Seraguek, Semerebuk, Ramos Tihion Tamping, Sijane, Rom Lambo, Sirias, Sigupai Pulo, Bo Santet Semantok, Bo Rayek Semantok Wayla, Cantek Manis, Rom Ilang dan Siputeh berbeda sangat nyata dibandingkan panjang lesio pada genotipe pembanding IR-BB27 (Tabel 7). Hal ini menunjukkan bahwa genotipe tersebut rentan terhadap HDB.

Reaksi 71 genotipe yang diuji dengan bakteri Xanthomonas oryzae pv. oryzae pada fase vegetatif sangat bervariasi mulai dari tahan, moderat tahan sampai rentan (Tabel 8). IR-64 menunjukkan reaksi rentan, sedangkan IR-BB27 menunjukkan reaksi tahan terhadap penyakit HDB. Dengan demikian, varietas IR64 cocok digunakan sebagai kontrol rentan dan IR-BB27 cocok digunakan sebagai kontrol tahan terhadap HDB.

Pada penelitian ini, ditemukan empat belas genotipe yang tahan terhadap bakteri Xoo berdasarkan panjang bercak (Ogawa et al., 1988). Bercak pada daun dari genotipe tersebut tidak berkembang dan hanya kering berwarna coklat tua pada ujung daun dengan panjang lesio kurang dari $3 \mathrm{~cm}$. Genotipe yang tahan terhadap HDB adalah Inpari 1, Limboto, Tuwoti, Inpari 10, Lekat Rambot Linuet, Rom Mokot, Paki Gajah, Tamboen, Bo 100, Sipasie, Bo Minyek, Bontok, Sirendeh Semantuk Wayla dan Sambei (Tabel 8). Genotipe

Tabel 6. Rata-rata panjang lesio pada beberapa genotipe dibandingkan dengan genotipe IR-BB27 pada genotipe padi lokal Aceh tipe ketan

\begin{tabular}{|c|c|c|}
\hline No & Genotipe ketan & Panjang lesio $(\mathrm{cm})$ \\
\hline 1 & IR-BB27 & 1,42 \\
\hline 2 & Leukat Rambot Lineut & 3,06 tn \\
\hline 3 & Lekat Adang & $5,39 * *$ \\
\hline 4 & Lekat jerajak Lango & $6,45 * *$ \\
\hline 5 & Pulut Hitam & $6,75 * *$ \\
\hline 6 & Lekat Singke & $8,40 \quad * *$ \\
\hline 7 & Lekat Alahu & $8,78 * * *$ \\
\hline 8 & Ketan Putih & $9,10 \quad * *$ \\
\hline 9 & Pulut Merah & $10,13 * *$ \\
\hline 10 & Pulut Simanik & $10,82 * *$ \\
\hline 11 & Lekat Kumbob & $17,00 \quad * *$ \\
\hline 12 & Lekat Tuleng & $19,93 * *$ \\
\hline
\end{tabular}

tn $=$ tidak nyata $; *=$ sangat nyata dibandingkan IR-BB27 
Tabel 7. Rata-rata panjang lesio pada beberapa genotipe dibandingkan dengan genotipe IR-BB27 padi lokal bukan ketan

\begin{tabular}{|c|c|c|c|}
\hline \multirow{2}{*}{$\frac{\text { No }}{1}$} & \multirow{2}{*}{$\begin{array}{l}\text { Genotipe lokal bukan ketan } \\
\text { IR-BB27 }\end{array}$} & \multicolumn{2}{|c|}{ Panjang lesio $(\mathrm{cm})$} \\
\hline & & 1,42 & \\
\hline 2 & Rom Mokot & 1,91 & tn \\
\hline 3 & Paki Gajah & 2,20 & tn \\
\hline 4 & Tamboen & 2,26 & tn \\
\hline 5 & Bo 100 & 2,36 & tn \\
\hline 6 & Sepasie & 2,56 & tn \\
\hline 7 & Bo Minyek & 2,94 & tn \\
\hline 8 & Bontok & 2,99 & tn \\
\hline 9 & Sirendeh Semantuk Wayla & 3,03 & tn \\
\hline 10 & Sambei & 3,20 & tn \\
\hline 11 & Pade Jamai Asan & 4,00 & $*$ \\
\hline 12 & Salah Manyang & 4,37 & $*$ \\
\hline 13 & Arias & 4,53 & $*$ \\
\hline 14 & Pandan Wangi & 4,68 & $*$ \\
\hline 15 & Pade Merah Lamtuba & 4,80 & $*$ \\
\hline 16 & Bo Somboh Meon & 5,41 & $* *$ \\
\hline 17 & Sigupai Wangi & 5,45 & $* *$ \\
\hline 18 & Kuku Balam & 5,96 & $* *$ \\
\hline 19 & Kepala Gajah & 6,22 & $* *$ \\
\hline 20 & Asahan & 6,37 & $* *$ \\
\hline 21 & Manyam & 6,58 & $* *$ \\
\hline 22 & Boh Penileh & 6,71 & $* *$ \\
\hline 23 & Saguek & 6,71 & $* *$ \\
\hline 24 & Dewi & 6,72 & $* *$ \\
\hline 25 & Jeumpa Puteh & 6,90 & $* *$ \\
\hline 26 & Sigupai Blang Pidie & 6,99 & $* *$ \\
\hline 27 & Pala Gajah & 7,05 & $* *$ \\
\hline 28 & Rangkoh Merah & 7,14 & $* *$ \\
\hline 29 & Pade Kapai Tamping & 7,15 & $* *$ \\
\hline 30 & Padi Sitandun & 7,16 & $* *$ \\
\hline 31 & Sirangkoh Lubok Pasi & 7,37 & $* *$ \\
\hline 32 & Sepulou & 7,60 & $* *$ \\
\hline 33 & Pade Pineng Lango & 7,63 & $* *$ \\
\hline 34 & Seraguek & 7,87 & $* *$ \\
\hline 35 & Semerebuk & 8,29 & $* *$ \\
\hline 36 & Ramos Tihion Tamping & 8,70 & $* *$ \\
\hline 37 & Sijane & 8,89 & $* *$ \\
\hline 38 & Rom Lambo & 8,89 & $* *$ \\
\hline 39 & Sirias & 8,92 & $* *$ \\
\hline 40 & Sigupai Pulo & 8,97 & $* *$ \\
\hline 41 & Bo Santet Semantok & 9,01 & $* *$ \\
\hline 42 & Bo Rayek Semantok Wayla & 9,25 & $* *$ \\
\hline 43 & Cantek Manis & 9,25 & $* *$ \\
\hline 44 & Rom Ilang & 9,36 & $* *$ \\
\hline 45 & Siputeh & 14,74 & $* *$ \\
\hline
\end{tabular}

tn = tidak nyata; $*$ nyata; $* *=$ sangat nyata dibandingkan IR-BB27. 
Tabel 8. Pengelompokan ketahanan genotipe padi terhadap Xanthomonas oryzae pv. oryzae pada fase vegetatif berdasarkan panjang lesio

\begin{tabular}{ccl}
\hline No & Kriteria & \\
\hline 1. & Tahan & $\begin{array}{l}\text { IR-BB27, Inpari 1, Limboto, Tuwoti, Inpari 10, Lekat Rambot Linuet, Rom Mokot, Paki } \\
\text { Gajah, Tamboen, Bo 100, Sipasie, Bo Minyek, Bontok, Sirendeh Semantuk Wayla dan }\end{array}$ \\
& & Sambei \\
2. & Moderat & Danau Gaung, IPB 4S, Situ Bagedit, Inpago, Cirata, IPB 3S, Pade Jamai Asan, Salah \\
& Tahan & Manyang, Arias, Pandan Wangi dan Pade Merah Lamtuba. \\
3. & Rentan & Inapri 16, Ciherang, Situ Patenggang, Kencana Bali, Inpari 19, Inpari 7, IR-64, Lekat \\
& & Alahu, Lekat Singke, Pulut Hitam, Pulut Simanik, Pulut Merah, Lekat Tuleng, Lekat \\
& Kumbob, Lekat jerajak Lango, Lekat Adang, Ketan Puth, Bo Somboh Meon, Sigupai \\
& Wangi, Kuku Balam, Kepala Gajah, Asahan, Manyam, Boh Penileh, Saguek, Dewi, \\
& Jeumpa Puteh, Sigupai Blang Pidie, Pala Gajah, Rangkoh Merah, Pade Kapai Tamping, \\
& Padi Sitandun, Sirangkoh Lubok Pasi, Sepulou, Pade Pineng Lango, Seraguek, \\
& Semerebuk, Ramos Tihion Tamping, Sijane, Rom Lambo, Sirias, Sigupai Pulo, Bo \\
& Santet Semantok, Bo Rayek Semantok Wayla, Cantek Manis, Rom Ilang dan Siputeh \\
\hline
\end{tabular}

tersebut memiliki gen-gen ketahanan terhadap penyakit HDB dapat digunakan untuk membentuk varietas unggul dan tahan penyakit HDB melalui pemuliaan tanaman. Sifat unggul spesifik yang dimiliki padi lokal perlu diinkorporasikan ke dalam genom varietas unggul agar memiliki sifat unggul yang unik. Varietas lokal dengan sifat-sifat unggul perlu dilestarikan sebagai aset sumber daya genetik nasional dan dimanfaatkan dalam program pemuliaan (Sitaresmi et al., 2013).

Pada penelitian ini, dijumpai 11 genotipe yang moderat tahan menunjukkan infeksi dan gejala layu pada ujung daun dan warna putih kecoklatan dengan panjang lesio mencapai 3-6 cm. Diperoleh juga 48 genotipe yang rentan terhadap penyakit HDB. Reaksi gejala layu pada ujung daun dan bercak kelabu pada tepi daun genotipe tersebut sudah dimulai 3 hari setelah inokulasi, kemudian daun mulai berkerut pada 14 hari setelah inokulasi seluruh bagian daun mulai berwarna putih kecoklatan dan kuning pucat menuju pangkal daun. Pada genotipe yang menunjukkan gejala moderat tahan dan rentan terhadap HDB, patogen sangat cepat berkembang terutama pada keadaan lembab. Penyakit HDB ini mampu menghasilkan ras baru, sehingga sering menyulitkan pengendalian dengan varietas tahan. Gnanamanickam et al. (1999) menyatakan bahwa penyakit HDB merupakan penyakit yang menginfeksi secara sistemik dengan gejala berupa bercak berwarna abu abu putih di sepanjang tulang daun.

Patogen masuk melalui hidatoda. Luka pada daun tanaman juga merupakan jalan masuk yang potensial bagi patogen. Kebanyakan infeksi yang berhasil terjadi melalui luka dibandingkan dengan yang melalui hidatoda, dan luka yang masih baru lebih kondusif bagi patogen dibandingkan dengan luka yang sudah lama. Panjang lesio pada tanaman padi dipengaruhi oleh sinar matahari dan suhu selama perkembangan penyakit, latar belakang genetik dari galur yang digunakan, konsentrasi inokulum, dan virulensi (Ogawa et al., 1988).

\section{SIMPULAN}

Masa inkubasi paling lama terdapat pada genotipe IR-BB27, Limboto, Inpari 10, Situ Patenggang, Sirendeh Semantuk Wayla, Tamboen, Sepasie, Bontok dan Arias. Sedangkan masa inkubasi tercepat terdapat pada genotipe Inpago 6, Danau Gaung, Kencana Bali, Inpari 16, Inpari 7, Lekat Alahu, Pulut Simanik, Lekat Tuleng, Lekat Kumbob, Pulut Merah, Asahan, Boh Penileh, Sirias, Dewi, Kuku Balam, Seraguek, Sigupai Pulo, Sirangkoh Lubok Pasi, Bo Somboh Meon, Sigupai Wangi, Bo Santet Semantok, Saguek, Cantek Manis, Jeumpa Puteh, Ramos Tihion Tamping, Salah Manyang, Semerebuk, Sijane, Kepala Gajah, Siputeh, Rangkoh Merah dan Pade Merah Lamtuba. Genotipe yang tahan terhadap HDB dijumpai pada Inpari 1, Limboto, Tuwoti, Inpari 10, Lekat Rambot Linuet, Rom Mokot, Paki Gajah, Tamboen, Bo 100, Sipasie, Bo Minyek, Bontok, Sirendeh Semantuk Wayla dan Sambei. Genotipe yang menunjukkan reaksi moderat tahan dijumpai pada Danau Gaung, IPB 4S, Situ Bagedit, Inpago, Cirata, IPB 3S, 
Pade Jamai Asan, Salah Manyang, Arias, Pandan Wangi dan Pade Merah Lamtuba. Namun genotipe yang menunjukkan reaksi rentan terhadap HDB dijumpai pada Inapri 16, Ciherang, Situ Patenggang, Kencana Bali, Inpari 19, Inpari 7, IR-64, Lekat Alahu, Lekat Singke, Pulut Hitam, Pulut Simanik, Pulut Merah, Lekat Tuleng, Lekat Kumbob, Lekat jerajak Lango, Lekat Adang, Ketan Putih, Bo Somboh Meon, Sigupai Wangi, Kuku Balam, Kepala Gajah, Asahan, Manyam, Boh Penileh, Saguek, Dewi, Jeumpa Puteh, Sigupai Blang Pidie, Pala Gajah, Rangkoh Merah, Pade Kapai Tamping, Padi Sitandun, Sirangkoh Lubok Pasi, Sepulou, Pade Pineng Lango, Seraguek, Semerebuk, Ramos Tihion Tamping, Sijane, Rom Lambo, Sirias, Sigupai Pulo, Bo Santet Semantok, Bo Rayek Semantok Wayla, Cantek Manis, Rom Ilang dan Siputeh.

\section{SANWACANA}

Penulis mengucapkan terimakasih kepada Universitas Syiah Kuala, Kementerian Pendidikan dan Kebudayaan, yang telah membiayai sebagian dana penelitian ini melalui Penelitian Unggulan Perguruan Tinggi Tahun Anggaran 2014.

\section{DAFTAR PUSTAKA}

Abdullah B. 2009. Progress of rice improvement through recurrent selection. J. Agron. Indones. 37(3): 188-193.

Bakhtiar, Kesumawati E, Hidayat T, \& Rahmawati M. 2011. Karakterisasi plasma nutfah padi lokal Aceh untuk perakitan varietas adaptif pada tanah masam. Agrista 15(3): 79-86.

Berthaud J, Clement JC, Emperaire L, Louette D, Pinton F, Sanou J, \& Second G. 2000. The role of locallevel geneflow in enhancing and maintaining genetic diversity. In: Cooper HD, Spillene C, \& Hodgken (Eds.). Broadening the Genetic Base of Crops Production. pp. 81-104. IGRI, FAO, CABI Publishing, Wallingford.

Devadath S. 1989. Chemical control of bacterial blight of rice. In: Bacterial Blight of Rice. pp. 89-98. IRRI, Manila. Philippines.

Gnanamanickam SS, Priyadarisini VB, Narayanan NN, Vasudevan P, \& Kavitha S. 1999. An overview of bacterial blight disease of rice and strategies for its management. Curr. Sci. 77(11): 1435-1443.
Herlina L \& Silitonga TS. 2011. Seleksi lapang ketahanan beberapa varietas padi terhadap infeksi hawar daun bakteri strain IV dan VIII. Bul. Plasma Nutfah 17(2): 80-87.

Klement Z, Stall RE, Novacky A, Ersek T, Fett T W, Huang J, \& Beckman C. 1990. Mechanism of resistance. In: Klement Z, Rudolph K, \& Sands DC (Eds.). Methods in Phytobacteriology. pp. 469-473. Budapest, Hungary.

Nino-Liu DO, Ronald PC, \& Bogdanove AJ. 2006. Xanthomonas oryzae pathovars: model pathogens of a model crop. Mol. Plant Pathol. 7(5): 303-324.

Ogawa T, Busto GA, Tabien RE, \& Khush GS. 1988. Further study of $X a-4 b$ gene for resistance to bacterial blight of rice. Rice Genetics Newsletter 5: 104-105.

Ou SH. 1985. Rice Diseases. Second edition. Commowealth Mycological Institute. The Cambrian News, Aberystwyth.

Rahim A, Khaeruni A, \& Taufik M. 2012. Reaksi ketahanan beberapa varietas padi komersial terhadap patotipe Xanthomonas oryzae pv. oryzae isolat Sulawesi Tenggara. Berkala Penelitian Agronomi 1(2): 132-138.

Shehzad FD, Farhatullah, Iqbal N, Shah SMA, \& Ahmad M. 2012. Screening of local rice germplasm against bacterial leaf blight caused by Xanthomonas oryzae pv. oryzae. Sarhad J. Agric. 28(4): 565-569.

Sitaresmi T, Wening RH, Rakhmi AT, Yunani N, \& Susanto U. 2013. Pemanfaatan plasma nutfah padi varietas lokal dalam perakitan varietas unggul. Iptek Tan. Pangan 8(1): 22-30.

Sudir, Nuryanto B, \& Kadir TS. 2012. Epidemiologi, patotipe, dan strategi pengendalian penyakit hawar daun bakteri pada tanaman padi. Iptek Tanaman Pangan 7(2): 79-87.

Suswanto A, Friska H, \& Sudirman I. 1996. Karakterisasi Pseudomonas fluorescens B29 dan B39; profil DNA genom, uji hipersensitivitas, dan asai senyawa bioaktif. Hayati 3(1): 15-20.

Wahyudi AT, Meliah S, \& Nawangsih AA. 2011. Xanthomonas oryzae pv. oryzae bakteri penyebab hawar daun pada padi: isolasi, karakterisasi, dan telaah mutagenesis dengan transposon. Makara Sains 15(1): 89-96. 
Wiyono S. 2007. Perubahan iklim dan ledakan hama dan penyakit tanaman. Makalah Seminar Sehari tentang Keanekaragaman Hayati di tengah Perubahan Iklim: Tantangan Masa Depan Indonesia. pp.1-10. Jakarta. 18 Juni 2008.
Zou LF, Wang XP, Xiang Y, Zhang B, Li YR, Xiao YL, Wang JS, Walmsley AR, \& Chen GY. 2006. Elucidation of the hrp clusters of Xanthomonas oryzae pv. oryzicola that control the hypersensitive response in nonhost tobacco and pathogenicity in susceptible host rice. Appl. Environ. Microbiol. 72(9): 6212-6224. 